\title{
100 YEAR COMMEMORATION OF THE ARMENIAN GENOCIDE, APRIL 24, 2015 - SYDNEY TOWN HALL SPEECH
}

\author{
Geoffrey Robertson QC
}

On August 22, 1939, Adolf Hitler summoned his generals to a villa in Salzburg and in a shockingly brutal speech, urged them to show no mercy towards local women and children when invading Poland - there would be no retribution, because, he said, "after all, who now remembers the annihilation of the Armenians?” The blitzkrieg crimes and the annihilation of Jews and Roma, and other minorities, were committed by Nazis who believed they would have the same impunity that 20 years before had been granted those who oversaw the extermination of over half the Armenian population. In 1915, Armenians were rounded up and community leaders killed; the perpetrators executed able-bodied men and then sent women, children and old men on marches into the Syrian desert, knowing that hundreds of thousands would die. The Ottoman Turks may not have used gas ovens, but they used death squads, starvation, typhus, and concentration camps in places we have only heard of today because they are now being overrun by ISIS. Their intention was to destroy Armenians as a Christian people, killing them to cries of "Allah Akbar" whilst passing laws to seize their homes, lands and churches, because they were not coming back to those homes and lands and churches, which have never been restored to them.

Historically, there is an interesting link between the Armenian Genocide and Australia that has gone largely unnoticed. It began, as genocides often do, with the arrest and murder of the intelligentsia: Armenian scholars, writers and community leaders, rounded up in Constantinople (now Istanbul) on April 24, 1915, the night before the dawn landing at Gallipoli. That was no coincidence. As the Turkish army prepared to repulse the Gallipoli landing, the Young Turk Government took the opportunity to begin the physical extermination of those it termed "the enemy within." This was a people of 2 million who had lived there since before the birth of Christ, and were the first to convert to Christianity in 301 AD, a century before it became the religion of the Roman Empire. They had lived on in the Ottoman Empire under the Muslim caliphate of the Sultan, but as a despised minority, and the Gallipoli landing was used as an excuse to begin a genocide that took over a million civilian lives.

What now do we owe to those lives, people butchered and starved as 
the result of internal state planning during a world war that the Ottomans had opportunistically entered on the side of Germany? The Armenians were not killed in war, they were killed under the cover of war. I compare their deaths with that of my own grand-uncle on the beach at Gallipoli on 24 April. William Robertson, or "Piper Bill" as he was known (he played the bagpipes in the Leichhardt Town Band), pretty quickly copped a load of bullets in "Sniper's Alley." He had volunteered to fight and was killed, lawfully, by Turkish soldiers defending their own land. Piper Bill is owed no special mourning a century on, other than sadness at the futility of this war, and anger perhaps at the stiff-necked and stupid political leaders who took their nations to war and refused, for over four years, to contemplate a peace agreement. The million or so Armenians who died because of massacres and deportations were, by contrast, victims of a crime against humanity. Should they be remembered a century on, merely as victims of war, like Piper Bill? I believe they have a special claim on our memory, and on our thinking about how to avoid such atrocities now and in the future.

There is, of course, an international debate about whether Armenian massacres and deportations amount to genocide. Turkey denies it and insists that all Armenian deaths following the decrees of the Young Turk government were justified. Most democracies in Europe, however, have recognised this as genocide, and some have even made it a crime to deny it. The debate even touched Australia when the speaker of the Turkish parliament threatened politicians from New South Wales with exclusion from ANZAC Day ceremonies at Gallipoli because in 2013 they had voted to recognise the genocide.

Former Prime Minister Tony Abbott followed in the footsteps of Barack Obama, who proclaimed during his first presidential campaign in 2008 that, "The Armenian genocide is a widely documented fact supported by an overwhelming body of historical evidence. The facts are undeniable — as President, I will recognise the Armenian genocide.” But Obama reneged and dropped any use of the g-word, preferring instead Meds Yeghern, an Armenian word that means nothing to Americans. Obama does call it "one of the worst atrocities of the 20th century" in which, he says, 1.5 million Armenians were brutally massacred. He goes on to say elliptically, "I've already said what my opinion is on what happened in 1915. It has not changed." If you want his opinion on what happened to the Armenians you have to Google his 2008 speech to find that he believes it was genocide. It is a word he does not utter for fear of Turkish reprisals: the closing of spy bases or airfields currently used to pummel ISIS.

The truth is too inconvenient to utter. Turkey is simply too important to NATO for governments to speak the truth. 43 state legislatures in America have recognised the genocide, but not the US. In Britain, where Scottish and 
Welsh parliaments have recognised the crime, the UK government will say anything to avoid expressing the inconvenient truth. It disingenuously claimed that the evidence for genocide is "not sufficiently unequivocal." The reason for this I discovered in some secret memoranda obtained under the Freedom of Information Act-Turkey is "neuralgic" on the subject. "We are unethical," the Foreign Office secretly admitted, "but given the importance of our political, strategic and commercial relations with Turkey, UK equivocation was the only convenient option.”

Because of all this genocide equivocation, I have attempted to settle the issue in my book, An Inconvenient Genocide: Who Now Remembers the Armenians? by applying the law to the facts agreed upon by historians. My conclusion, beyond any doubt, is that the Armenian people were victims of genocide as defined by the Genocide Convention and by the Statute of the International Criminal Court. I will not weary you with the evidence, and I will not describe in detail the massacres, the Euphrates River so swollen with dead bodies that it changed its course, the beheading of boys and the selling into sexual slavery of girls, the forced conversions to Islam, and so on.

The Armenian minority in the Ottoman Empire had always been denied civil rights and been allocated the title of an inferior status. In 1894-1896, the period of the first massacres, 200,000 were killed, which was warning enough to the Young Turk Government that took power in 1909, of underlying racial and religious tensions. That government increased these tensions by a "Turkification" programme that stressed racial superiority and demeaned the Armenians, referring to them as tubercular microbes on the body politic. The government even changed the names of streets and towns, from Christian to Muslim. They banned the use of the name "Armenian" from companies and associations, and refused to teach the Armenian language in schools. At the outset of the war, their tame Imam declared a Jihad against Christians, although he had to, somewhat embarrassingly, exempt Germans as they were Ottoman allies.

In April 1915 came the roundup of the intellectuals, the call-up of Armenian men to be placed in army labour battalions and then massacred, and the deportation law that required all Armenians without exception to be deported. This meant relocation to the Syrian desert where most died either from starvation on the long march, or from typhus and dysentery in camps beyond Aleppo. Then came the laws that expropriated their property as "abandoned," a euphemism for confiscation. It is interesting to compare the euphemisms used to cover up genocide: Adolf Eichmann's Wannsee Conference minutes talk of "evacuation" of Jews to the east, because of wartime necessity. The Young Turk Government similarly spoke of "relocating" the Armenians be- 
cause of wartime necessity. Both governments knew they were transporting people (the Armenians mainly on foot) to their deaths.

Evidence of the Ottoman Turkish government's genocidal intentions comes from many sources, most compellingly from their allies, the Germans, whose consuls reported to Berlin that the Turks were bent on extinguishing the Armenians as a group. They were very worried that Germany would be held complicit in what the British, French and Russians denounced as "a crime against humanity,” and they urged Chancellor Theobald von Bethmann-Hollweg, and the Kaiser, to take action. They refused. "It's unheard of to criticise your ally in the middle of a war," replied the Chancellor. The American diplomats, neutrals at this stage, were appalled by the destruction. Talaat Pasha, the Turkish Interior Minister, made no bones about his determination to destroy the community: "We are solving the Armenian question by eliminating the Armenians,” he told Henry Morgenthau, the US ambassador. There is telling evidence from German and American missionaries, from Austrian and Italian diplomats, from captured Australian diggers (themselves treated decently enough by the Turks), who reported with some horror how their captors would massacre Armenians and send them off to starve. At the end of the war, an extensive enquiry led by American General James Harbord described this as "the most colossal crime of all the ages . . . this wholesale attempt on a race.”

Well, that is genocide in my book and by definition of Raphael Lemkin, the brilliant Polish law professor who coined the word and the concept. Lemkin was bothered by the fact that there was no international criminal law that would punish the perpetrators of state-sponsored racist massacres outside of their own country. The British had rounded up 68 of the main Turkish officials, taken them for trial in Malta, but discovered they had no jurisdiction to try political or military leaders for killing their own people. In 1919, there was no international criminal law. The main perpetrators were given refuge by Germany, and in 1922 Talaat Pasha was assassinated by a vigilante whose family had died in the deportations. The jury heard defence evidence from German generals and missionaries, and acquitted the assassin.

Lemkin thought you could not leave genocide to the justice of the vigilante. It was a peculiar and horrific event that should be made an international crime, with the states of the world obliged to punish it. He examined its history, from the destruction of Carthage to the latest twentieth century example that he gave as the destruction of the Armenians. It was this event that inspired his campaign throughout the 1930s, and it gained momentum with the Nazi genocide. Lemkin lobbied all the embassies of the war. He was a pain in the neck and the Canadians, to get rid of him, palmed him off on the Australian, Dr Herbert Evatt, who could also be a pain in the neck. These two legal geniuses 
hit it off and Evatt was the statesman who supported Lemkin and who introduced the Genocide Convention at the UN in 1948 as President of the General Assembly.

So the whole concept of an international law against genocide was inspired by the Armenian experience, which was not, as the Australian Government now says, a tragedy. It was a crime, and is now the worst crime of all, with a Convention that obliges the world to act against its perpetrators.

It is important to understand that genocide does not mean that the target group is extinguished. It is sufficient if part of the group is intended for destruction. There was genocide, the International Court of Justice has ruled, in Srebrenica, when 7,000 Muslim men and boys were killed, and 18,000 women deported. Nor does it mean killing or injuring. Genocide includes, by Convention definition: "deliberately inflicting on the group conditions of life calculated to bring about its physical destruction in whole or part.” There can be no doubt, therefore, that what happened to the Armenians in 1915 was genocide. It is true that no court has yet held this to be the case, and all books about it have been written by historians. Mine is the first, I think, by an international lawyer.

But the evidence is overwhelming. Why, then, does Turkey dispute it? First, it states that there were only 1.1 million Armenians in the country at the time, so 1.5 million could not have died. It estimates the death toll at "only" 600,000 and I put "only" in inverted commas, because 600,000 is over half of 1.1 million. In any event, the Armenian Church records, far more likely to be accurate, count 2.1 million. So "only 600,000" is hardly a sensible objection. Then the Turkish Government says that the "relocations," as they put them, were for "military necessity." That does not excuse the massacres, which they put down to a few "unruly officials." "Unruly" is another of genocide's euphemisms, intended to cloak barbarism ordered by the government. As for the "relocations," what was the military necessity in killing children, women and old men? Necessity in war can never justify the deliberate murder of civilians: if suspected of treason or loyalty to the enemy they may be detained or interned or prosecuted, but not sent on death marches from which they are not expected to return.

This Turkish argument, promoted by a massive propaganda exercise in the run-up to the genocide's centenary, is very dangerous. Deliberately killing civilians can never be justifiable in order to gain a military advantage. There were, admittedly, dangers on the Russian front, and there were some Armenians who defected to the Russian army, and there were some outbreaks of violence from Armenians, generally in self-defence. Only in one town, Van, did they succeed in driving out the Turkish army and then only for two months. 
The danger of giving legal credence to the Turkish argument is that it would apply to all genocides where there is civil resistance. It would justify Rajapaksa in Sri Lanka, killing up to 70,000 civilians in order to eliminate the Tamil Tigers. It could be used by the Pakistani army to justify the killing of 3 million Bengalis back in 1971, because they harboured a small number of freedom fighters. It is during war that the law of genocide is most necessary to protect minority groups, and it is ironic that the Turkish government denies genocide of the Armenians on the pretext that they were "the enemy within" during a war, the very circumstances in which special obligations on a state to protect racial or religious groups are essential.

That is why genocide trials continue today in The Hague for those perpetrators of Srebrenica: five Bosnian Serb generals have been convicted, and it is only a matter of time before General Mladić joins them. Srebrenica, a Muslim enclave surrounded by a predominantly Serb-populated countryside, in the racially jumbled geography of Bosnia, was attacked by Bosnian Serb commanders who did not, merely by taking the town, commit genocide. That happened shortly afterwards when Mladić ordered the deportation of all Muslim women, children and old men, whilst at the same time about 7,000 able-bodied men and boys were separated and detained, ostensibly to "screen" them for war crimes, but in fact to be carted off, killed and buried in mass graves that later yielded corpses with hands tied behind backs, shot from behind. Remember the incriminating footage that came from a private camcorder, with grainy images of Muslim men and boys huddled in fields, surrounded by soldiers who wait impatiently to be blessed by Serb Orthodox priests so they can, with easy consciences, shoot their prisoners before nightfall. The International Criminal Tribunal for the Former Yugoslavia (ICTY) and the International Court of Justice have concluded that the operations- the deportations and the massacre-prove that, "the Bosnian Serb forces not only knew that the combination of the killings of the men with the forcible transfer of the women, children and elderly would inevitably result in the physical disappearance of the Bosnian Muslim population of Srebrenica, but clearly intended through those acts to physically destroy this group." That is what the Ottoman leaders clearly intended to do to the Armenians of Eastern Anatolia in 1915.

So what are we to make of the massively-funded Turkish government denialism of crimes committed by their predecessors in 1915? It goes beyond denialism. Under S.301 of the Turkish Criminal Code, citizens can be, and are, prosecuted for asserting that there was a genocide. Hrant Dink, a courageous newspaper editor, was assassinated and the government did nothing to bring his assassins to justice. Schoolchildren are taught to write essays refut- 
ing the genocide. The press restrictions are such that Turkey is rated 154th in league tables of press freedom, largely because of its ban on criticism of Ottoman behaviour.

Of course, it was a long time ago, but 100 years is still within living memory. Several elderly women who were small children when carried by their mothers across the burning sands, were invited to tea with President Obama in 2015, along with the world's most famous Armenian, Kim Kardashian. And, of course, the mental scars, the psychological trauma on their children and grandchildren, continues throughout the diaspora, and will continue until Turkey makes some acknowledgement of the crime, and some reparation.

International law may provide some assistance, as it has with art looted by the Nazis: there are assets expropriated in 1915 that can still be traced. Over 1,000 seized churches could be given back. One church, at Lake Van, was restored and returned a few years ago, which gives some hope of resolution. Armenians want their historic lands restored, but that is probably asking too much. I have suggested that the majestic and mysterious Mount Ararat that overlooks the capital, Yerevan, could be restored to Armenians as an act of reconciliation. What Armenians most want is an acknowledgement of the dreadful crime that was committed, and if Turkey chokes on an admission of genocide, it should at least admit that its Ottoman predecessor committed a crime against humanity - there can be no conceivable legal argument that the massacres and deportations did not amount to that.

Turkey, outrageously, claims that if the 1915 events did not amount to genocide, they amounted to nothing at all: "c'est la guerre," as if "military necessity" in war can justify the marching of hundreds of thousands of civilians to their death. That this is a war crime of utmost gravity was confirmed by the American and Australian military courts that convicted Japanese generals for the death marches in the Philippines and at Sandakan. Their victims were soldiers who were prisoners of war: to subject civilians to the same treatment is a crime that "military necessity" can never justify, any more than it could justify General Mladić's destruction of Muslims in Srebrenica on the ground of strategic advantage for his army and his cause.

Genocide, because it is the worst crime against humanity, calls for a special study of its causes and for special precautions against its recurrence. There are lessons to be learned from the way in which a new and seemingly progressive "Young Turk" government decided to solidify its support behind the banner of racial superiority, and how this in turn led its intellectual theorists to demonise and dehumanise the Armenian minority. Genocide scholarship serves a valuable purpose of identifying patterns that recur in the build-up to behaviour in which formerly happy neighbours are incited to hack each other to 
death, renouncing the very notion of "neighbourhood" as a living space that human beings of different creeds or colours can amicably occupy. Within living memory, murderous hatred has been inflicted on Hindus and Bengalis of Bangladesh, on Tutsis in Rwanda, Muslims of Bosnia-Herzegovina, Tamils of Sri Lanka, Chechens in Russia, Mayans in Guatemala, Chinese in Indonesia, Darfurians in Sudan, and on other victim groups; currently on Christians and Yazidis by ISIS. The list is long and it will lengthen unless the world remembers the Armenians and rejects the claim that their killing was no more than cruel necessity or, as polite genocide deniers always say, like the Australian Government, "It was a tragedy.” It was not a tragedy. It was a crime. 